\title{
Lexical Standards for Expository Writing at Grade 3: The Transition from Early Literacy to Academic Literacy
}

\author{
HETTY ROESSINGH \\ Werklund School of Education, University of Calgary \\ SCOTT DOUGLAS \\ University of British Columbia \\ BROCK WOJTALEWICZ \\ Werklund School of Education, University of Calgary
}

\begin{abstract}
This article reports on an investigation of vocabulary thresholds in Grade 3 children's writing samples across four quality standards scored by way of a trait-based rubric. The students attend a publically funded school jurisdiction of choice within a large urban setting and are average achievers on provincially mandated student learning assessments of reading and writing in Grade 3. Both quantitative and qualitative methods were used to analyze the first draft writing $(\mathrm{N}=222)$ in response to an expository prompt. A quota sampling strategy was used to create a learner corpus comprised of 20 papers for each of the four quality standards. Online lexical profiling tools were used to generate indices of lexical variability. Distinct differences in vocabulary use were noted between quality standards, in particular the ability to access low frequency words among the samples judged of excellent quality. Pedagogical implications emerge for classroom practitioners to address the language learning needs of linguistically vulnerable youngsters.
\end{abstract}

Keywords

expository prose, writing, transitional literacy, vocabulary profiling

\section{Introduction}

Grade 3 marks a significant turning point in children's written literacy development. There is a discernable shift in cognitive development and the concomitant growth and sophistication in vocabulary use. Children generally may be expected to have control over the lower level development skills of printing and spelling (Berninger, 1999; Christensen, 2009; Graham, 2009; Graham \& Santangelo, 2014; McCutchen, 2011; Pontert et al, 2013; Medwell \& Wray, 2008, 2014) and thus, large scale writing assessments are often implemented at this juncture.

This investigation seeks quantitative research insights into vocabulary use visible in children's writing and further considers qualitative insights gleaned from looking holistically at children's writing at the end of Grade 3. Two broad questions guide this inquiry:

1) What patterns of lexical diversity are salient in children's writing across 4 quality standards (Limited, Adequate, Proficient, Excellent)?

2) What qualitative evidence emerges from children's writing that provides insights into the writing process? 
This inquiry makes a unique contribution to the extant research in illuminating the patterns of vocabulary use in children's written work that are possible through recent advances in technology enhanced vocabulary profiling software available in the public domain, and corpus linguistics methodologies that have emerged in tandem with the software development. As an adjunct to trait-based approaches to writing assessment, data generated from vocabulary profiles can direct attention to children's language learning needs that must be addressed through instructional planning by elementary classroom practitioners (Biemiller, 2001). This is a key consideration, given the rapidly shifting demographic landscape in today's classroom, reflected in linguistic diversity across Canada, the United States, the UK and Australia in addition to other linguistically vulnerable youngsters, such as those raised in poverty (Chall \& Jacobs, 2003).

\section{Literature Review}

Composing text is a multifaceted and complex process that involves two broad categories of knowledge and skills: transcription and text generation. Transcribing is largely concerned with automatizing the lower level developmental skills of printing and spelling and is associated with early written literacy learning. Research evidence from the neurosciences underscores the importance of printing in producing quality text (Berninger, 1994; Christensen, 2009). Similarly, spelling knowledge contributes to better writing outcomes in early literacy development by the end of Grade 2 (Berninger \& Fayol, 2008; Joshi, Treiman, Carreker, \& Moats, 2008; Roessingh \& Elgie, 2014). Text generation involves the processes of planning and organizing thought, and accessing and mobilizing available lexical resources in the service of producing quality text by the end of Grade 3. As children transition from early literacy to academic literacy development, vocabulary knowledge plays an increasing role in producing quality text, the focus of our inquiry (Biemiller, 2003; Chall \& Jacobs, 2003; DiCerbo, Anstrom, Baker, \& Rivera, 2014; Schleppegrell, 2012). In this section, we briefly review the literature on the intertwining development of vocabulary and cognition, and we address assessment issues as these relate to our methodological approach in identifying quality standards in Grade 3 writing.

\section{The Primacy of Vocabulary Knowledge}

Cummins (1984) posits a framework for understanding the development of language and cognition in a mutually reinforcing and unfolding relationship described as basic interpersonal communication skills (BICS) and cognitive academic language development (CALP). Adult-child talk mediates cognitive development as children begin to name, describe, categorize and make sense of their expanding world from an early age. Over time, language itself is needed to represent complex, abstract thought: the use of metaphor is a key feature of CALP.

We adopt Cummins' framework for the purposes of our work because it is widely accepted and recognized in the field and provides an accessible entry point for the discussion surrounding the role of language in learning, and language in academic writing: the reciprocal relationship between language and cognition. In Figure 1 we highlight the features of each and though they are presented in juxtaposed fashion, it is important to underscore that they develop along a continuum that is gradual and protracted. 


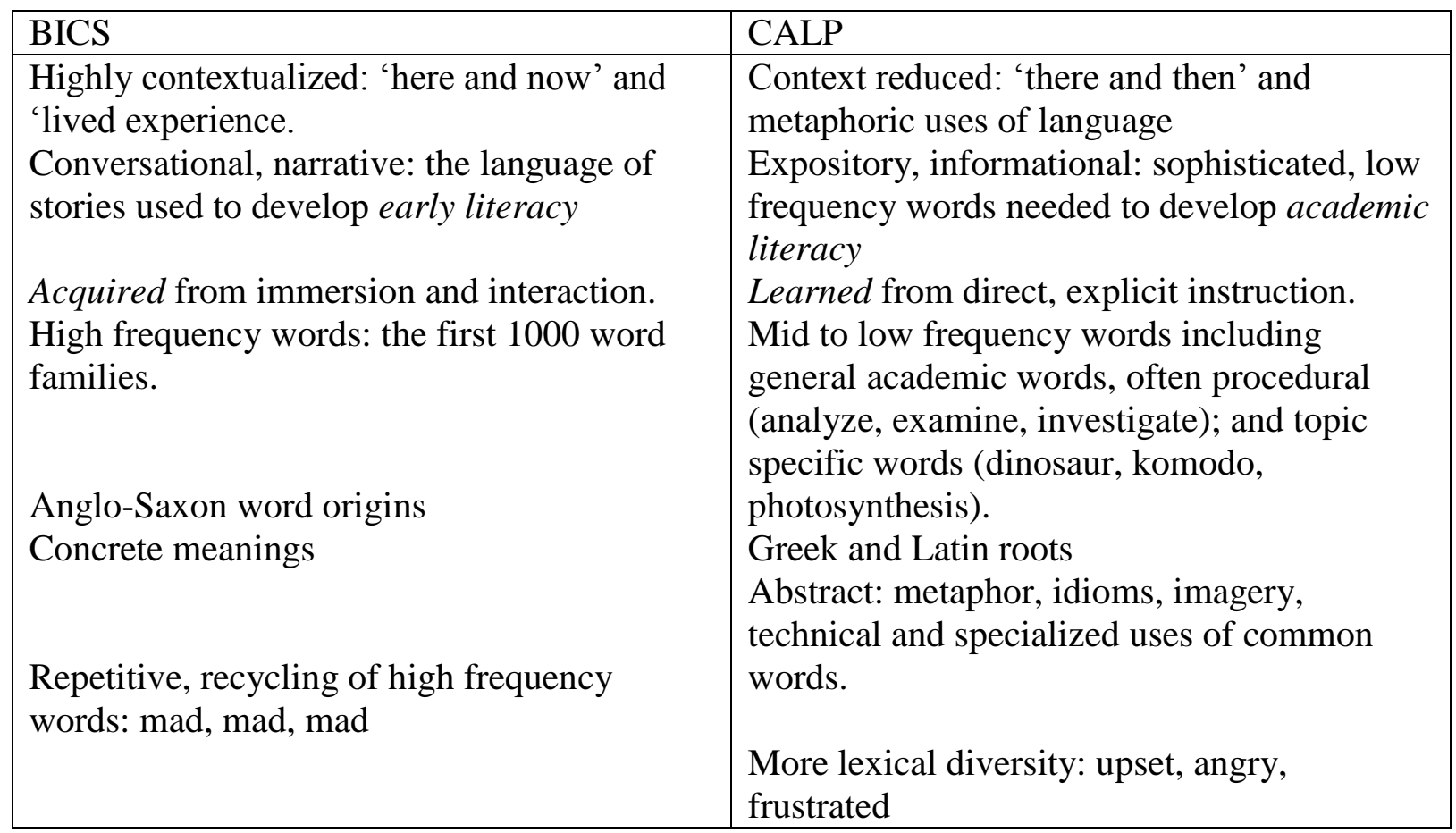

Figure 1. Features of BICS and CALP

Children's emergent literacy learning is reflected in their attempts to convey meaning through drawing and scribbling messages often only they can decipher. Rather quickly, by the end of Grade 1, they become proficient and increasingly accurate at mapping the sounds and the words in their oral repertoire to their representation in print (Biemiller, 2003; Graham \& Santagelo, 2014). Concomitantly, they gain control over the neuro-motor demands of printing (Roberts, Derkach-Ferguson, Siever \& Rose, 2014). These early literacy benchmarks are generally achieved with familiar, high frequency words (BICS): perhaps a few hundred words that contain all the phonics rules and patterns needed to achieve this feat (Roessingh, 2013). There is a latency period of perhaps two years during which children continue to develop vocabulary knowledge but are constrained in their ability to apply these words to literacy tasks, until they have 'cracked the code' and automatized the lower level foundational skills of printing and spelling. The transition to academic literacy that follows relies on the ability to unleash their expanding vocabulary repertoire of rare and sophisticated words associated with Cummins' (1984) conceptualization of CALP.

Various researchers identify vocabulary knowledge as the critical ingredient leading to academic literacy (Biemiller, 2003; Chall \& Jacobs, 2003; Schleppegrell, 2012). Chall and Jacobs (2003) coined the term 'the grade 4 slump' to refer to the phenomenon of children who fail to transition from learning to read, to reading to learn - associated with a lack of vocabulary knowledge at this threshold. Reading and writing rely on analogous underlying processes and skills, and thus, unsurprisingly, better readers at high levels tend also to be better writers with the important caveat that they demonstrate control over the lower level developmental skills of printing and spelling (Yates, Berninger, \& Abbott, 1995).

Breadth and depth of vocabulary knowledge affords precision and nuance of meaning, and it is at the level of vocabulary use that control of grammar may be demonstrated. Halliday and Hasan's (1976) seminal work underscores the notion that writers create cohesion through vocabulary choices, a key feature of quality writing. Strategic selection of general nouns (nouns 
having general references to people, places, things/objects, actions), synonyms, super-ordinates, and collocations (words that 'go together' in a lexical bundle: 'boys and girls, 'peace and quiet') for example, all serve to realize cohesion.

Children who have productive capability with these words are likely to have learned them from challenging, collaborative and elaborative conversations and discussions at home, beginning at an early age (Hart \& Risley,2003). Developing a corpus of these types of words that are visible in children's writing provides an invaluable starting point for considering the 'next words to know' in addressing the learning needs of youngsters who do not otherwise have ready access to them. While teachers increasingly attend to the meanings of topic or subject specific vocabulary (Snow, 2010), they tend to ignore the high utility, general academic vocabulary that travels across curricular boundaries (Duke, 2000; Scott, Jamieson-Noel \& Asselin, 2003), and that are central to academic literacy.

\section{Cognitive Development}

Children reach an important milestone in their cognitive growth at age $8-9$. In Piagetian terms (Isaacs, 1974), children reach the stage of object permanency or constancy and are able to manipulate objects in space, firmly establishing themselves as structured thinkers. Piaget described this stage as 'concrete operational'. Concepts related to size, shape, number, distance, length, and class inclusion, for example, coalesce. Nevertheless, many children still benefit from a real-world concrete reference point: recall that writing, as a representational system for spoken language, still traverses several processes in the working memory from its ideational origins in thought. Talking, drawing and coloring are all useful precursors to the written word (Collelo, 2001).

Cognition also begins to become more complex and abstract. This is evidenced in the use of increasing numbers of words of Greek and Latin origin. Thus, 'design' is a more complex construct than 'draw'; 'create' vs 'make', 'construct' vs 'build'. Hundreds of these words begin to appear in the informational texts that children of this age are expected to access (Schleppegrell, 2012).

Children at this age are also increasingly able to think about or reflect on their thinking (Schneider, 2008). This step toward metacognitive awareness allows for children to review, revise and edit their work, for example, and also to deploy planning strategies in the pre-writing phase of the writing process. Many young writers can move beyond coloring and drawing, and are able to benefit from preparing a simple outline, or a semantic web containing key words they would like to use in their writing.

\section{Assessment of Early Literacy}

Just as the pedagogy of early literacy is a contested field, so it follows with assessment approaches. These are dependent on epistemological views of what constitutes the teaching and learning of literacy practices. The role of the teacher, the types and topics of writing, the place of explicit and direct teaching in foundational skills are all part and parcel of a debate that has remained fragmented over the past four decades (Gardner, 2012; Goodman, 1989; Ivanic, 2010; Luke, 2013). The common thread that unites the discussion is the concern over writing achievement at all levels, beginning at an early age. Moreover, this concern is noted internationally. The UK, Australia, Canada, the United States all face the need to educate students to advanced levels of literacy development to remain competitive in a complex, globally connected economy, yet achievement outcomes remain stubbornly disappointing beginning at the early stages of literacy development and reflecting a steady decline over time ( Roessingh, 2012a; Statistics 
Canada, 2009; Wray \& Medwell, 2006). Reaching high levels of academic literacy requires accelerating levels of various types of discourse knowledge, including vocabulary.

It becomes clear from the foregoing discussion that regardless of theoretical orientation to the teaching and learning of literacy practices, vocabulary knowledge plays a key role in the process of composing quality text. Others in the research community have focused on this same question (Olinghouse \& Leaird, 2009; Olinghouse \& Wilson, 2013).

The affordances of recently developed web based vocabulary profiling tools available in the public domain together with evolving corpus and computational methodologies permit fine grained quantitative insights into productive vocabulary knowledge manifest in a language sample, either oral or written (www.lextutor.ca/vp/kids). In essence, lexical profiling involves the comparison of a language sample to a levelled corpus of children's productive vocabulary arranged in order of frequency. The vocabulary profiling software used for our analysis cited above is based on a corpus comprised of 2500 word families of children's oral vocabulary knowledge at age 5 6 (Stemach \& Williams, 1988). It is organized by way of 10 levels or bands of 250 word families (i.e. run, runs, running counts as one word family) from high frequency (level 1) to low frequency (level 10). Words that are beyond level 10 are registered as 'Off-list' words. A validation study of this reference corpus (Roessingh \& Elgie, 2009) and the lexical profiling strategy that underlies the online tool confirms for us the utility of both this tool and the approach to language sample analysis it affords for the purposes of our research reported here. It appears that patterns in children's vocabulary development remain remarkably stable over time (Biemiller \& Slonim, 2001), and although they may acquire different content words (tiddly winks has turned into warrior games) the general, high utility academic words that are characteristic of CALP-like discourse have not changed. Over time, we expect to see a shift in the shape of individual vocabulary profiles, reflecting increasing access to low frequency, and sophisticated words, including those that are counted as 'Off-list'.

The online tool generates various indices of vocabulary diversity that reflect on the relationship between vocabulary knowledge and quality writing standards for young learners, including the total number of words (TNW), or tokens, in the sample and the number of different words (NDW), or types. In addition, various measures of what is sometimes called lexical sophistication or rare words, based on word frequency, are generated (Read, 2000). Control over this oral vocabulary and the movement beyond these words (recorded as Off-list words on the profiler tool) is consistently linked with reading comprehension (Biemiller, 2003) and quality writing, and this relationship strengthens and endures over the educational trajectory.

We take the position that holistic assessment from a trait-based rubric, the most common assessment approach currently utilized in large scale assessment programs, can be complemented with vocabulary profiling data, providing quantitative insights into children's vocabulary knowledge and cognitive development. The protocol and the prompt for eliciting the writing sample, however, are of great importance. In our study design, we were mindful of the need for authenticity in task, purpose and audience; developmental appropriateness and cognitive demand for setting the lexical bar; and background knowledge and accessibility to the content of the prompt (Roessingh, 2012b). In addition, we adopted a process approach to elicit and support the child's best efforts in producing the writing sample. This included pre-writing activities such as a brief teacher-led discussion to provide focus and understanding of the task at hand, to activate background knowledge; and to involve children in coloring, drawing, webbing, and outlining or planning with the support of a graphic organizer to scaffold their writing efforts. 
As an adjunct to qualitative assessment by way of trait based rubrics, these data give teachers, researchers, and other stake-holders important additional information that can guide instructional practices and curriculum design. For us, productive vocabulary knowledge as manifest in written contexts that reflect precision and correct usage provides the litmus of truly 'owning' a word.

\section{Methodology}

In this section we provide information on the research setting to offer a context for the study, details about the procedures, scoring and data analysis, and we note the limitations of the study.

\section{Research setting and participants}

Following a research ethics protocol from the University of Calgary (certificate \# 5982), expository writing samples were collected from 11 classes of Grade 3 students $(\mathrm{N}=222)$ all of whom attend a single, publically funded $(\mathrm{K}-12)$ school district within a large, urban center. This school district has a distinct instructional focus on teaching foundational skills. A programmatic approach to the teaching of printing, spelling, and phonics information is adhered to and consistently implemented by all teachers in the $\mathrm{K}-6$ grades. This is a school of choice, and most children are bused to their school location. There are 8 campuses across the city that attract diverse learner demographics, however, the students are overall typical learners. Outcomes on provincially mandated tests of reading and writing at the Grade 3 level reflect provincial patterns of achievement in early literacy learning.

\section{Procedures}

A prompt for eliciting expository prose was chosen and field tested in order to sample the full range of children's productive vocabulary knowledge (Roessingh, Elgie \& Kover, 2015). This was central to question \#1 of our inquiry. We refer to our prompt as The Empty Space (see Appendix A, Writing prompt). Pre-writing activity allowed for some teacher talk and 'think-pairshare' to focus the children's thoughts and to ensure they understood the writing task. Drawing, coloring and other pre-writing activity was also encouraged before the students were set to the task of writing. To glean insights into children's independent level of writing abilities, we collected first draft writing. The students' regular classroom teachers administered the writing task within classroom time. The samples were collected at the end of the school year and masked at the school level to protect the identity of the student authors before being transferred to us.

\section{Scoring and Data Analysis}

The writing samples were marked for quality standard by way of a trait-based rubric adopted from the Edmonton Public Schools (2008) Highest Level Achievement Test (HLAT: see Appendix B), and assigned a holistic score. The writing samples were rated by two independent researchers who were trained in the use of the rubric. Ratings assigned were 1: Limited; 2: Satisfactory; 3: Proficient; and 4: Excellent. The two sets of ratings were highly correlated, at greater than .98 . The slight differences between the two raters were reconciled to form a combined final rating (Johnson, Penny, Fisher \& Kuhs, 2003; Stemler, 2004).

The samples were then digitized and all errors corrected in preparation for vocabulary profiling. The online profiling tool does not recognize misspelled words, allocating them to the 'Off-list' category where they skew the vocabulary profile. The digitized texts were submitted to 
the online vocabulary profiling tool developed for the purposes of analyzing children's oral or written production described earlier (www.lextutor.ca/vp/kids ).

Out of a possible pool of 222 writing samples, 80 texts were chosen through quota sampling to represent a balanced range of quality standards of writing. Each quality standard of writing was represented by 20 writing samples. This resulted in a corpus of 6,435 running words. In the 80 samples, 35 were written by boys and 45 were written by girls.

Using the VP-kids profiler, vocabulary profiles were generated for each writing sample, and data were recorded for various lexical measures including the total number of words (tokens), the total number of different words (types), Band 1 word coverage (representing the 250 highest frequency word families), cumulative Bands $1-4$ coverage (representing 1000 highest frequency word families), Off-list coverage (representing language beyond the Band 10 of children's oral productive word knowledge), and the lexical stretch (the lowest frequency Band writers are able to reach in a writing sample).

Once the lexical measures for each writing sample were obtained, descriptive statistics were generated for the means and standard deviations at each quality standard of writing. Oneway between subjects ANOVAs were calculated to compare the vocabulary measures at the varying quality standards of writing. IBM SPSS Statistics 20 was used to carry out the statistical calculations.

\section{Limitations of Our Study}

Our study is confined to one small school jurisdiction of 3,000 students, chosen strategically for its strong focus on foundational learnings and basic skills instruction in the $\mathrm{k}-3$ years, thus providing a level of confidence that differences in vocabulary use - the focus of our inquiry - could not be attributed to weaknesses in the printing and spelling. A previous study of a Grade 2 cohort from this school jurisdiction (Roessingh, 2013) reflected this strong focus in the early literacy program. Nevertheless, this presents its own limitations. The school is a school of parental choice, hence there is a self-selection element at play, reflected in the overall demographic profile of the school. While students are overall considered to be typical young learners, we are cognizant of factors related to school culture (e.g. uniforms; a consistent, school-wide designed instruction that focuses on foundational learnings and basic skills development, consistent expectations and assignment of homework) and parental expectations that play a role in children's early literacy development.

Secondly, by deciding on quota sampling as a strategy for standard setting we are clearly limited by the relatively small sample size of only 20 papers for each standard. While all 11 classes $(\mathrm{N}=222)$ submitted writing samples for our study, only 20 reached the standard of excellence. This figure, however, mirrors larger scale provincial Ministry assessment data as well as the findings of other studies indicating relatively few young students currently attain this level of achievement (Alberta Education, 2012).

Finally, it should be noted that adoption of the trait-based rubric for the purposes of this study represents simply one perspective of writing. However, a perusal of the research on the development of writing reflects a high degree of consensus concerning the features or traits of good quality writing including interesting ideas and topic development, organization, word choice, and conventions. 


\section{Results}

The first measure investigated across the four quality standards of writing was the total number of words, tokens, per writing sample. Results are summarized in Table 1.

Table 1

Average Tokens and Quality Standards of Writing $(n=80)$

\begin{tabular}{lllll}
\hline & Minimum & Maximum & $M$ & $S D$ \\
\hline 1 & 28 & 174 & 64.30 & 33.94 \\
2 & 72 & 227 & 125.25 & 38.76 \\
3 & 81 & 310 & 162.85 & 50.14 \\
4 & 132 & 418 & 265.75 & 80.83 \\
\hline
\end{tabular}

A one-way between subjects ANOVA was carried out to compare the mean tokens at varying quality standards of writing. The number of tokens had a significant effect on the quality standards of writing, $F(3,76)=48.84$, p $<0.01$. Post hoc analyses with the Tukey HSD test indicated that the mean tokens were significantly different for all measures $(p<0.05)$ except for between quality standards 2 and 3. Thus, it appears that the total number of words in a text has an effect on ratings of writing quality. However, this effect is less profound in distinguishing between quality standards 2 and 3 . It can be noted that, in general, higher ratings of writing quality were accompanied by longer texts.

Next, the total number of different words, types, per writing sample. Results are summarized in Table 2.

Table 2

Average Types and Quality Standards of Writing $(n=80)$

\begin{tabular}{lllll}
\hline & Minimum & Maximum & $M$ & $S D$ \\
\hline 1 & 23 & 73 & 40.25 & 12.71 \\
2 & 42 & 103 & 68.80 & 17.17 \\
3 & 55 & 139 & 86.80 & 19.73 \\
4 & 82 & 188 & 125.90 & 27.66 \\
\hline
\end{tabular}

The one-way between subjects ANOVA revealed that the total types had a significant effect on the quality standards of writing, $F(3,76)=63.86, \mathrm{p}<0.01$. Post hoc analyses with the Tukey HSD test indicated that the mean types were significantly different for all measures $(\mathrm{p}<0.05)$. These results suggest a relationship between the total number of different words in a text and ratings of writing quality, with higher ratings of writing quality generally accompanied by a greater variety of vocabulary choices.

The third measure under investigation is the percentage coverage of text by Band 1 in the VP-kids vocabulary profiler. Results are summarized in Table 3. 
Table 3

Percentage Band 1 Coverage and Quality Standards of Writing $(n=80)$

\begin{tabular}{lllll}
\hline & Minimum & Maximum & $M$ & $S D$ \\
\hline 1 & 62.20 & 84.72 & 74.31 & 6.24 \\
2 & 58.33 & 78.20 & 69.54 & 6.67 \\
3 & 59.60 & 74.05 & 67.74 & 4.60 \\
4 & 56.99 & 75.61 & 67.49 & 5.41 \\
\hline
\end{tabular}

The one-way between subjects ANOVA indicated that the percentage Band 1 coverage had a significant effect on the quality standards of writing, $F(3,76)=5.98, \mathrm{p}<0.01$. Post hoc analyses with the Tukey HSD test indicated that the percentage Band 1 coverage was significantly different between Quality Standards 1 and 3 and Quality Standards 1 and 4 ( $<<0.05)$. However, there were no significant differences between the other quality standards. Generally, the higher the quality standard, the less textual coverage was accounted for in Band 1. Furthermore, it appears that the percentage coverage of a text by Band 1 is most easily differentiated between the lowest and highest quality standards. Writers judged to be at Quality Standard 1 rely more on Band 1 word choices than writers judged to be at Quality Standards 3 and 4.

The fourth measure explored was that of the percentage coverage of text by Bands 1 to 4 combined. Results are summarized in Table 4.

Table 4

Percentage Coverage of Bands 1-4 Combined and Quality Standards of Writing $(n=80)$

\begin{tabular}{lllll}
\hline & Minimum & Maximum & $M$ & $S D$ \\
\hline 1 & 81.49 & 97.56 & 91.50 & 3.66 \\
2 & 81.82 & 95.83 & 88.75 & 3.10 \\
3 & 79.47 & 93.13 & 86.63 & 3.57 \\
4 & 78.79 & 91.69 & 85.15 & 3.96 \\
\hline
\end{tabular}

The one-way between subjects ANOVA indicated that the percentage coverage of text by Bands 1-4 combined had a significant effect on the quality standards of writing, $F(3,76)=11.82$, $\mathrm{p}<0.01$. Post hoc analyses with the Tukey HSD test indicated that the percentage coverage of text by Bands 1-4 combined was significantly different between Quality Standards 1 and 3, 1 and 4, and 2 and $4(\mathrm{p}<0.05)$. However, the means were not significantly different between Quality Standards 1 and 2, 2 and 3, and 3 and 4. These results indicate that there was a general trend of less reliance of the first four bands of the VP-kids, but the differences were more pronounced between quality standards at the opposite ends of the rubric (i.e. Limited:1; and Excellent: 4).

The fifth lexical measure under consideration was the percentage coverage of text accounted for by words not covered by the VP-kids reference corpus (i.e. Off-list). Results are summarized in Table 5. 
Table 5

Percentage Coverage by Off-List and Quality Standards of Writing $(n=80)$

\begin{tabular}{lllll}
\hline & Minimum & Maximum & $M$ & $S D$ \\
\hline 1 & 0.00 & 6.67 & 3.30 & 2.12 \\
2 & 1.11 & 7.49 & 3.95 & 1.90 \\
3 & 1.00 & 7.95 & 5.17 & 2.16 \\
4 & 1.28 & 12.25 & 5.73 & 2.57 \\
\hline
\end{tabular}

The one-way between subjects ANOVA indicated that the percentage coverage of text by Off-List word choices had a significant effect on the quality standards of writing, $F(3,76)=5.10$, $\mathrm{p}<0.01$. Post hoc analysis with the Tukey HSD test indicated that the percentage coverage of text by Off-list word choices was significantly different between Quality Standards 1 and 3 and 1 and 4 ( $\mathrm{p}<0.05)$. However, there were no significant differences between the other quality standards. Generally, the percentage coverage by Off-list word choices increased as the rater judgments of writing quality increased. In addition, while differences between adjacent quality standards were not statistically significant, the opposite ends of the rubric (i.e. Standard 1 vs 4 ) did reach statistical significance.

The final lexical measure investigated the lexical stretch: how far students were able to tap into the low frequency bands. Results are summarized in Table 6.

Table 6

Lexical Stretch and Quality Standards of writing $(n=80)$

\begin{tabular}{lllll}
\hline & Minimum & Maximum & $M$ & $S D$ \\
\hline 1 & 1 & 11 & 4.10 & 2.22 \\
2 & 4 & 11 & 7.25 & 2.43 \\
3 & 5 & 11 & 8.75 & 2.22 \\
4 & 8 & 11 & 10.85 & 0.67 \\
\hline
\end{tabular}

The one-way between subjects ANOVA indicated that the lexical stretch had a significant effect on the quality standards of writing, $F(3,76)=39.80, p<0.01$. Post hoc analysis Tukey HSD test indicated that the lexical stretch was significantly different between all quality standards $(\mathrm{p}<$ 0.05) except for between Standard 2 and 3. Generally, the lexical stretch improved with increased rater judgments of writing quality. Results are summarized in Table 7.

Table 7

Summary of Mean Lexical Features for Quality Standards of Writing

\begin{tabular}{lllllll}
\hline $\begin{array}{l}\text { Quality } \\
\text { Standard }\end{array}$ & Tokens & Types & $\begin{array}{l}\text { Band 1 } \\
\text { Coverage }\end{array}$ & $\begin{array}{l}\text { Bands 1-4 } \\
\text { Coverage }\end{array}$ & $\begin{array}{l}\text { Off-List } \\
\text { Coverage }\end{array}$ & $\begin{array}{l}\text { Lexical } \\
\text { Stretch }\end{array}$ \\
\hline 1 & 64.30 & 40.25 & 74.23 & 91.50 & 3.30 & 4.10
\end{tabular}




\begin{tabular}{lllllll}
2 & 125.25 & 68.80 & 69.54 & 88.75 & 3.95 & 7.25 \\
3 & 162.85 & 86.80 & 67.74 & 86.63 & 5.17 & 8.75 \\
4 & 265.75 & 125.90 & 67.49 & 85.15 & 5.73 & 10.85 \\
\hline
\end{tabular}

Lexical profiling tools also allow for the identification of mid and low frequency words 'juicy words' that appear in the students' writing. Figure 2 below displays words from the Academic Word List (AWL: Coxhead, 2000) highlighted in red. The remaining words are overwhelmingly from Bands 5 and beyond the 2500 word families (i.e. Band 10) represented by the reference corpus used in creating the VP-kids profiling tool: the 'Off-list' words. Figure 2 displays these words.

Absolutely Activity Advance Amuse Altitude Approve Attach Balance Barrier Challenge
Collapse Combine Compares Complain Connected Convince Consider Coordination Create
Decline Depend Design Direction Disappointed Educational Entertain Environment Excellent
Equipment Exercise Exhausted Expensive Expert Fascinating Hilarious Imagine Imagination
Important Improve Include Involve Locate Maximum Mental Motion Natural Normal Objects
Obstacle Original Perfect Platform Physical Popular Possible Prevent Protect (protection
protective) Purpose Regular Related Recommend Recreation Safety Section Sense Similar
Spiral Solution Source Stimulate Strategy Strengthen Structure Suggestion Surface Suspend
Technically Various

Figure 2: AWL (red coded) and Off-list Words from Grade 3 Writing Samples

There are 80 'juicy words' in the corpus of words that appeared in the Grade 3 writing samples. The lexical stretch for children who are weaker writers is at Band 4, thus, these words are not yet in the productive vocabulary of many of these children.

Finally, we recorded features of children's writing that distinguished between weaker and stronger writers. Again, the differences between quality standards of writing is reflected in the ability to mobilize lexical resources in the service of creating precise, succinct and cohesive written text. Figure 3 provides some of the key features noted.

\begin{tabular}{|l|l|l|}
\hline Feature: & Good writers ... & Weaker writers ... \\
\hline $\begin{array}{l}\text { Sensitive to register, task } \\
\text { demand: }\end{array}$ & $\begin{array}{l}\text { 'I hope you will consider my } \\
\text { suggestions.' }\end{array}$ & $\begin{array}{l}\text { 'I hope you like / pick my } \\
\text { ideas' } \\
\text { 'This is what I really, really } \\
\text { want,' } \\
\text { 'Please pick mine.' }\end{array}$ \\
\hline Use of superordinates: & $\begin{array}{l}\text { Equipment, structures, } \\
\text { obstacles, items, activities }\end{array}$ & $\begin{array}{l}\text { Lists / names of things; } \\
\text { monkey bars, slides, swings }\end{array}$ \\
\hline Nuanced: & $\begin{array}{l}\text { Disappointed } \\
\text { Amusing, hilarious, } \\
\text { entertaining }\end{array}$ & $\begin{array}{l}\text { Sad, bored } \\
\text { Fun, fun, fun }\end{array}$ \\
\hline Precise: & $\begin{array}{l}\text { Spiral } \\
\text { Object }\end{array}$ & $\begin{array}{l}\text { Turn, twirl } \\
\text { Stuff, thing, mcthingy, a } \\
\text { thing where there is a pole in } \\
\text { the middle } \\
\text { Good }\end{array}$ \\
\hline
\end{tabular}




\begin{tabular}{|l|l|l|}
\hline & & Everyone will like it. \\
\hline $\begin{array}{l}\text { Lexical chunks and } \\
\text { collocations: }\end{array}$ & $\begin{array}{l}\text { Last but not least } \\
\text { Peace and quiet } \\
\text { Environmentally friendly }\end{array}$ & $\begin{array}{l}\text { Safety } \\
\rightarrow \text { protection } \rightarrow \text { dangerous } \\
\text { library } \rightarrow \text { read } \rightarrow \text { peace and } \\
\text { quiet }\end{array}$ \\
\hline Creates cohesion: & $\begin{array}{l}\text { Ideas are disjointed, not } \\
\text { elaborated. }\end{array}$ \\
\hline
\end{tabular}

Figure 3. Some Differences Between Good Writers and Weaker Writers at Grade 3

\section{Discussion}

This section is organized to address each of our two inquiry questions. The first related to patterns of lexical diversity visible in children's writing across 4 quality standards (Limited, Adequate- Proficient, Excellent).

Various patterns of vocabulary use become clear from the data presented in the preceding section. Table 7 summarizes these features. Most striking among the findings is the relationship between length (total number of words), the number of different words and the sophistication of the lexical choices, that is, the degree to which the writer was able to access the low frequency vocabulary. The greatest discrepancy is noted between writing judged to be excellent and that of limited quality. These findings align with those well established in the research (Sénéchal, Ouellette, \& Rodney, 2006; Stanovich, 1986). The literature indicates these early advantages in vocabulary knowledge endure over time.

The shift from early literacy to academic literacy is rapid and noticeable especially in Grade 3. It is marked by the accelerating shift of children's use of their vocabulary, once they have worked out the 'code' of language by hand (i.e. phonics information and spelling rules) and have good control over the kinesthetic demands of printing. It would appear that children with an advantage of a large lexical repertoire are almost immediately able to unleash vast vocabulary knowledge throughout the Grade 3 year. Thus, while early literacy is largely dependent on control over the lower level developmental skills, academic literacy is largely dependent on mobilizing vocabulary resources. In particular sophisticated, rare vocabulary that is being acquired all the while students are concentrating on learning to 'push the pencil' and to correctly spell the high frequency words available in their oral vocabulary repertoire can suddenly be deployed. Failure to traverse this linguistic threshold has also been associated with a related phenomenon described as 'the grade 4 slump' (Chall \& Jacobs, 2003). An over-emphasis on basic or foundational skills at the expense of early and ongoing vocabulary teaching may result in wash-out (Luke, 2013): the plateau/ceiling effect described by Chall and Jacobs of students 'hitting the wall' in grade 4. In fact, the beginnings of this hidden threat need to be identified much earlier among linguistically vulnerable youngsters (Sénéchal, Ouellette, \& Rodney, 2006). While Chall and Jacobs' study identified youngsters raised in poverty at heightened risk by Grade 4, English language learners (ELLs) may also be among those who can benefit from attention to vocabulary development (August, Carlo, Dressler \& Snow, 2005). Early identification and intervention is the key to improved learning outcomes for all children at educational risk for reasons related to vocabulary learning needs.

An analogy can be made to the development of young musicians. What sets the exceptional apart from those who plateau with simply technique is the ability to interpret the music - giving it both life and soul. This is only possible when the skills are under such exquisite control that the 
musician can transcend the notes on the page, losing him/herself in the flow and imparting to the audience a deeper, unique expression of the music (Bonfield, 2012). In a similar vein, excellent writing proficiency cannot bypass the need for control over the lower level developmental skills.

The data in Table 7 indicate the glaring discrepancy of literate vocabulary knowledge: weak writers access only about 1,000 (i.e. Band 4: 4 x 250) word families, whereas strong writers (standard 4) are able to tap into in excess of 2500 word families (10 x 250). More, writing represents productive vocabulary knowledge: receptive vocabulary (i.e. listening and reading) knowledge is estimated by many researchers to be significantly larger - perhaps as much as twice as large (Nation, 2001).

Our second research question related to qualitative insights into children's writing. Figure 3 summarizes this information and provides illustrative support from the children's writing samples. Adeptness at creating cohesion contributes in large measure to better writing, but once again we noted that this depends heavily on vocabulary knowledge. The use of open class nouns for categorizing objects such as equipment and structures, for example, is also evidence of cognitive development at the level of concrete operations delineated by Piaget. Cummins' BICSCALP model (1984) further describes this shift to cognitive academic language proficiency, and it is clearly evident in children's writing in fairly early stages. Many words from Coxhead's (2000) Academic Word List are already accessible to young learners. At a much younger age than previously thought, youngsters are sensitive to informational genres and register (Ravid \& Tolchinsky, 2002).

The students were given the opportunity to plan their writing as part of the writing process. While this was not directly scored, we noted with great interest the ways in which drawings and word webs, listing of ideas and recording key words, for example, connected to the writing. In better quality writing, planning was evident and the link was visible. Figure 4 below illustrates effective pre-writing activity. This student wrote about 'creating a wildlife park for education and amusement.' 


\section{PLANNING SHEET}

\section{Ideas:}
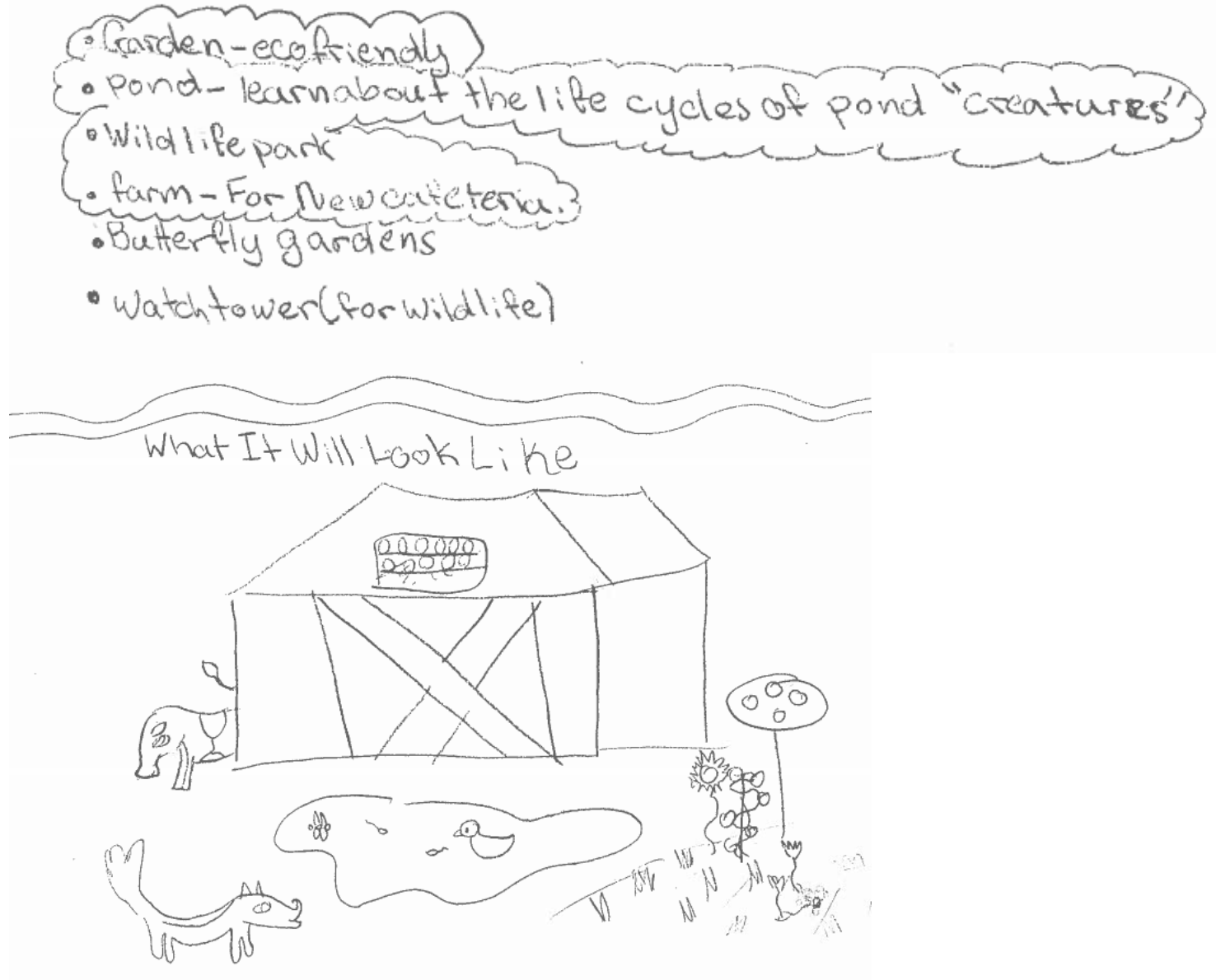

Figure 4. Pre-writing Activity. Excellent Quality Writing

Finally, students were asked to reflect on their writing. Many students demonstrated the beginning ability to describe their strengths and to think of ways to improve their work, in short, metacognitive and metalinguistic awareness. The young author below realizes as well, that convincing is a different task from storytelling, and thus requires rethinking of the use of vocabulary and discourse level language to make her pitch for building a new gym in the empty space. Figure 5 provides an example: 


\section{STUDENT INPUT}

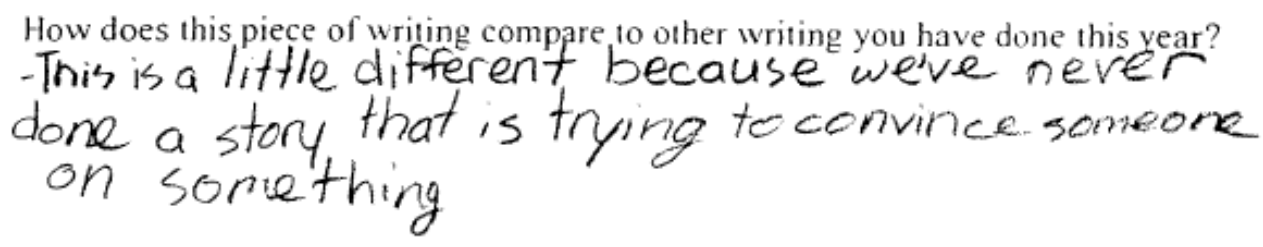

What is something you did well in this piece of writing?

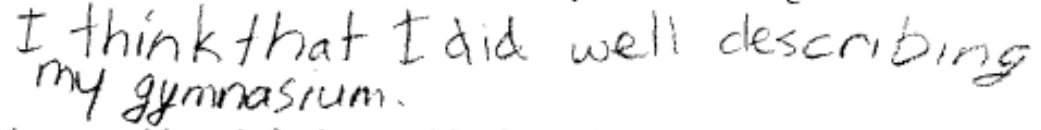

If you could work further on this piece of writing, what would you do?

I would add some other specialties

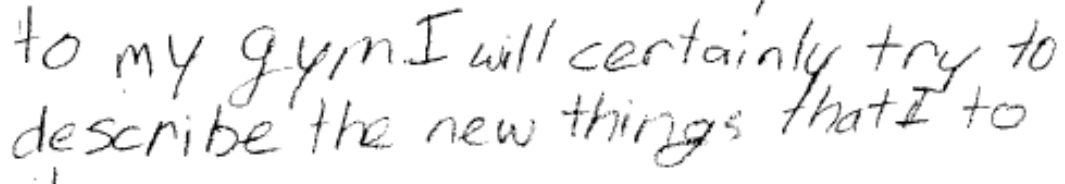

if.

Figure 5: Student reflections: Excellent Quality Writing

In the section that follows we identify some pedagogical implications that evolve from these findings and we make suggestions for future research.

\section{Conclusion}

Children leave indelible footprints of their linguistic and cognitive growth, visible in their writing efforts that unfold, often predictability, over time. Advances in online tools in the public domain, together with evolving methods in corpus and computational linguistics permit insights heretofore unavailable which can begin to inform instructional decision making. Children at heightened risk may be easier to identify, and, taking a cue from linguistic information revealed from vocabulary profiling, instruction can be more strategically targeted.

Pedagogical implications that emerge from this study underscore the importance of early and targeted interventions aimed at enhancing vocabulary knowledge for young learners who are linguistically vulnerable (Biemiller, 2001; DiCerbo, Anstrom, Baker, \& Rivera, 2014). There is a growing body of research that investigates promising practices for vocabulary teaching. These include dialogic storybook reading (Torr \& Scott, 2006) that involves elaborative and collaborative talk in the mold of socio-cultural theories of language development (Vygotksy, 1978). Van Kleeck (2008) also suggests the use of storybook reading to structure questions that promote cognitively complex responses such as making predictions and inferences. Duke (2000) makes the case for introducing far more informational texts including a wide variety of non-fiction literature that is increasingly available from commercially published sources. These contain the mid-range high utility academic words (i.e. those with Greek and Roman roots) that transfer across the curriculum, as well as interesting content words that fascinate youngsters (e.g. komodo).

Taking a cue from children who are already using low frequency and academic words in the productive efforts, teachers can strategically target new vocabulary for working with youngsters who can benefit from direct instruction with these words. Identifying 'big bang for 
your buck' words such as 'equipment' naturally makes connections to semantic neighbors and collocations such as safety, prevent, protection, exercise. Marzano and Marzano (1988) have long advocated teaching words in a cluster approach. Similarly, Neuman, Neuman and Dwyer (2011), exploit the potency of schema theory to accelerate vocabulary learning as children are able to bootstrap their own vocabulary knowledge once the properties and boundaries of a semantic field, or cluster, have been internalized. Identifying both the cluster and the difficulty level of the words contained therein is increasingly possible through the affordances of technology enhanced tools becoming available in the public domain, such as those utilized in this study.

In addition, the internet offers a trove of free and accessible materials for listening and reading. It is worth exploring how these may be used to extend children's language learning opportunities through well-structured learning tasks (Roessingh, 2014). The development of academic literacy involves new and more challenges as the educational trajectory moves ahead. Vocabulary is a key piece of this puzzle, and teachers must increasingly accept greater responsibility to provide for youngsters what their parents may not, for reasons no fault of their own (August, Carlo, Dressler \& Snow, 2005).

Directions for future research include longitudinal work tracking the arrival of new vocabulary, over time, in children's writing. Again, the affordances of technology make this work possible: comparing time 1 - time 2 samples from a lexical perspective is easily undertaken. Such studies would help to ascertain the distal impact of early interventions, and the points at which children might be in need of enhanced learning support.

For all children, regardless of proficiency level, language and cultural background, the step to literacy learning is a magical, mystical, complex process. Our continued work as researchers and practitioners can serve to demystify some of these elements, bridging theory to practice and back again as we seek to continually improve literacy learning outcomes for all of our young learners.

\section{References}

Alberta Education (2012). Alberta Achievement Tests. Subject bulletin. English language arts. August, D., Carlo, M., Dressler, C., \& Snow, C. (2005). The critical role of vocabulary development for English language learners. Learning Disabilities Research and Practice, 20(1), 50-57.

Beck, I. L., McKeown, M. G., \& Kucan, L. (2002). Bringing words to life: Robust vocabulary instruction. New York: Guilford.

Berninger, V. (1994). Reading and writing acquisition: A developmental neuropsychological perspective. Dubuque, IA: Brown \& Benchmark.

Berninger, V. (1999). The 'write stuff' for preventing and treating disabilities. Perspectives International Dyslexia Association. http://www.ldanh.org/docs/writestuff.pdf

Berninger, V., \& Fayol, M. (2008). Why spelling is important and how to teach it effectively. Encyclopedia of Language and Literacy Development (pp. 1-13). London, ON: Canadian Language and Literacy Research Network. http://www.literacyencyclopedia.ca/pdfs/topic.php?topId=234

Biemiller, A. (2001). Teaching vocabulary: Early, direct and sequential. American Educator, Spring, 2001. http://www.aft.org/newspubs/periodicals/ae/spring2001/biemiller.cfm

Biemiller, A. (2003). Oral comprehension sets the ceiling on reading comprehension. American Educator, Spring, 2003. http://www.aft.org/newspubs/periodicals/ae/spring2003/hirschsboral.cfm 
Biemiller, A. \& Slonim, N. (2001). Estimating root word vocabulary growth in normative and advantaged populations: Evidence for a common sequence of vocabulary acquisition. Journal of Educational Psychology, 93(3), 498-520.

Blake, B., \& Pope, T. (2008). Developmental psychology: Incorporating Piaget's and Vygotsky's theories in the classroom. Journal of Cross Disciplinary Perspectives in Education, 1(1), 59-67. http://mxtsch.people.wm.edu/Teaching/JCPE/Volume1/JCPE_2008-01-09.pdf

Bonfield, S. (2012). Interpretive skills are what set pianists apart. Calgary Herald, October 22, 2012, p. D6

Chall, J., \& Jacobs, V. (2003). Poor children's fourth grade slump. American Educator, Spring, 2003. http://www.aft.org/periodical/american-educator/spring-2003/classic-study-poorchildrens-fourth-grade-slump

Christensen, C. (2009). The critical role handwriting plays in the ability to produce high-quality text. In R. Beard, D. Myhill, J. Riley, \& M. Nystrand (Eds.), The Sage handbook of writing development (pp. 284-299). Thousand Oaks, CA: Sage Publications.

Cobb, T. (2007). www.lextutor.ca/vp/kids UQAM.

Collelo, S. (2001). The role of drawing in children's writing. Study presented at II Seminário sobre Letramento e Alfabetização of the 13th COLE - Congresso de Leitura do Brasil, in Campinas (SP), July 2001. Translated by "English for You". http://www.hottopos.com/rih6/silvia.htm

Coxhead, A. (2000). A new academic word list. TESOL Quarterly, 34(2), 213-238.

Cummins, J. (1984). Bilingualism and special education: Issues in assessment and pedagogy. Clevedon, England: Multilingual Matters.

DiCerbo, P., Anstrom, K., Baker, L., \& Rivera, C. (2014). A review of the literature on teaching academic language to English language learners. Journal of Educational Research, 84(3) 446 - 483. http://rer.sagepub.com/content/84/3/446.full.pdf+html

Dolch, E. (1948). Problems in reading. Champaign, IL; Garrard Press.

Duke, N.K. (2000). 3.6 minutes per day: The scarcity of informational texts in first grade. Reading Research Quarterly, 35 (202-24). http://www.ciera.org/library/reports/inquiry1/1-007/Report\%201-007.html

Edmonton Public Schools (2008). Evaluating English Writing. Teacher resource for Highest Level of Achievement Test, HLAT writing. 2008 Edition.

Gardner, P. (2012). Paradigms and pedagogy: Revisiting D'Arcy's critique of the teaching and the assessment of writing. English in Education, 46(2), 135-154.

Goodman, K. (1989). Whole language research: Foundations and development. The Elementary School Journal, 90 (2), 207-221.

Graham, S. (2009). Want to improve children's writing? Don't neglect their handwriting. American Educator, Winter 2009/10, 20 - 27, 40. http://www.aft.org//sites/default/files/periodicals/graham.pdf

Graham, S., Berninger, V., Abbott, R., Abbott, S., \& Whitaker, D. (1997). The role of mechanics in composing of elementary school students: A new methodological approach. Journal of Educational Psychology, 89 (1), 170-182.

Graham, S., \& Santangelo, T. (2014). Does spelling instruction make students better spellers, readers and writers? A meta-analytic review. Reading and Writing: An interdisciplinary journal. 27(9), 1703 - 1743.

Halliday, M., \& Hasan, R (1976). Cohesion in English. New York: Addison Wesley Longman. 
Hart, B., \& Risley, T. (2003). The early catastrophe: The 30 million word gap by age 3. American Educator, Spring 2003. https://www.aft.org/sites/default/files/periodicals/TheEarlyCatastrophe.pdf

Isaacs, N. (1974). A brief introduction to Piaget. Schocken.

Ivanic, R. (2010). Discourses of writing and learning to write. Language and Education, 18(3), 220-245. http://dx.doi.org/10.1080/09500780408666877

Johansson, V. (2008). Lexical diversity and lexical density in speech and writing: A developmental perspective. Lund University, Department of Linguistics and Phonetics: Working Papers, 53, 61-79.

Johnson, R. L., Penny, J., Fisher, S., \& Kuhs, T. (2003). Score resolution: An investigation of the reliability and validity of resolved scores. Applied Measurement in Education, 16 (4), 299-322.

Joshi, M., Treiman, R., Carreker, S., \& Moats, L. (2008). How words cast their spell: Spelling is an integral part of learning the language, not a matter of memorization. American Educator, Winter 2008-2009. 6 - 8. http://www.aft.org/pdfs/americaneducator/winter0809/joshi.pdf\#page=4

Luke, A. (2013). On direct and explicit instruction. The Australian Educator. http://eprints.qut.edu.au/63824/1/explicit.pdf

Marzano, R., \& Marzano, J. (1988). A cluster approach to elementary vocabulary instruction. ED293116. http://www.scsk12.org/schools/klondike.es/site/documents/MarzonoVocabulary.pdf

McCutchen, D. (2011). From novice to expert: Implications of language skills and writingrelevant knowledge for memory during the development of writing skill. Journal of Writing Research, 3 (1), 51-68

Medwell, J., \& Wray, D. (2008) Handwriting - a forgotten language skill? Language and Education, 22 (1), 34-47. ISSN 0950-0782 http://wrap.warwick.ac.uk/461/

Medwell, J., \& Wray, D. (2014). Handwriting automaticity: The search for performance standards. Language and Education, 28(1), 34-51. http://www.tandfonline.com/doi/pdf/10.1080/09500782.2013.763819

Nation, P. (2001). Learning vocabulary in another language. Cambridge, UK: Cambridge University Press.

Neuman, S., Newman, E., Dwyer, T., (2011). Educational effects of a vocabulary intervention on pre-schoolers' word knowledge and conceptual development. Reading Research Quarterly, 46(3), $249-272$.

Olinghouse, N., \& Leaird, T.(2009). The relationship between measures of vocabulary and narrative writing quality in second and fourth-grade students. Reading and Writing, 22, 545-565.

Olinghouse, N., \& Wilson, J. (2013). The relationship between vocabulary and writing quality in three genres. Reading and Writing, 26(1), 45-65. http://link.springer.com/article/10.1007\%2Fs11145-012-9392-5\#page-1

Pontart, V., Bidet-Ildei, C., Lambert, E., Morisset, P., Flouret, L., \& Alamargot, D. (2013). Influence of handwriting skills during spelling in primary and lower secondary grades. Frontiers in Psychology, 4, 818. http://www.ncbi.nlm.nih.gov/pmc/articles/PMC3817363/

Ravid, D., \& Tolchinsky, L. (2002). Developing linguistic literacy: A comprehensive model. Journal of Child Language, 29 (2), 417 - 447. 
Read, J. (2000). Assessing vocabulary. Cambridge: Cambridge University Press.

Roberts, G., Derkach-Ferguson, A., Siever, J., \& Rose, M. (2014). An examination of the effectiveness of Handwriting Without Tears® instruction. Journal of Occupational Therapy, 81(2), 102-113.

Roessingh, H., \& Elgie, S. (2009). Early language and literacy development among young ELL: Preliminary insights from a longitudinal study. TESL Canada Journal, 26(2), 24-45.

Roessingh, H. (2012a). The Grade 3 Provincial Achievement Tests: In need of revamping? Alberta Journal of Educational Research, 58 (3), 425- 443. http://ajer.synergiesprairies.ca/ajer/index.php/ajer/article/view/1057

Roessingh, H. (2012b). The importance of the prompt for eliciting language samples: Insights from research and considerations for practice. TexELT: Texas English Language Teaching, 1(1), 37-56. http://esl-almadina.com/wpcontent/uploads/2015/09/importance_of_the_prompt_textesol_2012.pdf

Roessingh, H. (2013). A look at Grade 2 Writing: Successes and challenges in early literacy development. Learning Landscapes, 7(1), 269-281. http://www.learninglandscapes.ca/images/documents/11-no13/roessingh.pdf

Roessingh, H. (2014). Teachers' roles in designing meaningful tasks for mediating language learning through the use of ICT: A reflection on authentic learning for young ELLs. Canadian Journal of Learning and Technology, Special Issue on ICT mediated language tasks, 40 (1), 1 - 24. http://www.cjlt.ca/index.php/cjlt/article/viewFile/782/387

Roessingh, H., Elgie, S., \& Kover, P. (2015). Using lexical profiling tools to investigate children's written vocabulary development in Grade 3: An exploratory study. Language Assessment Quarterly, 12 (1), 67-86. http://dx.doi.org/10.1080/15434303.2014.936603

Schleppegrell, M. (2012). Academic language in teaching and learning. Elementary School Journal, 112(3), 409-418. http://www.jstor.org/stable/10.1086/663297

Schneider, W. (2008). The development of metacognitive knowledge in children and adolescents: Major trends and implications for education. Mind, Brain and Education, 2 (3), 114-121. http://onlinelibrary.wiley.com/doi/10.1111/j.1751228X.2008.00041.x/abstract

Scott, J., Jamieson-Noel, D., \& Asselin, M. (2003). Vocabulary instruction throughout the day in twenty-three Canadian upper-elementary classrooms. Elementary School Journal, 103(3), $269-286$.

Sénéchal, M., Ouellette, G., \& Rodney, D. (2006). The misunderstood giant: On the predictive role of early vocabulary to future reading. In D. Dickinson \& S. Neuman (Eds) Handbook of Early Literacy Research, Vol. 2, 173-182. New York, NY: Guildford Press.

Snow, C. (2010). Academic language and the challenge of reading for learning about science. Science 328, 450 DOI: 10.1126/science.1182597 http://colabradio.mit.edu/wpcontent/uploads/2010/05/academiclanguage.pdf

Stanovich, K. (1986). Matthew effects in reading: Some consequences of individual differences in the acquisition of literacy. Reading Research Quarterly, 21(4), 360 - 407. https://my.psychologytoday.com/files/u81/Stanovich_1986_pdf

Statistics Canada (2009). Measuring up: Canadian results of the OECD PISA study. http://www.statcan.gc.ca/pub/81-590-x/81-590-x2010001-eng.htm ; http://www.gov.pe.ca/photos/original/eecd_pisareporE.pdf

Stemach, G., \& Williams, W. (1988). Word Express: The first 2500 words of spoken English. Novato, CA. Academic Therapy Publications. 
Stemler, S. E. (2004). A comparison of consensus, consistency, and measurement approaches to estimating inter-rater reliability. Practical Assessment, Research \& Evaluation, 9(4), 1 19.

Torr, J., \& Scott, C. (2006). Learning 'special words': Technical vocabulary in the talk of adults and preschoolers during shared reading. Journal of Early Childhood Research, 4(2), 153 167.

Van Kleeck, A. (2008). Providing pre-school foundations for later reading comprehension: The importance of and ideas for targeting inferencing in storybook shared interventions. Psychology in the Schools, 45(7), 627 - 643. http://onlinelibrary.wiley.com/doi/10.1002/pits.20314/epdf

Vygotsky, L.S. (1978). Mind in society: The development of higher psychological processes. Cambridge, MA: Harvard University Press.

http://www.cles.mlc.edu.tw/ cerntcu/099-curriculum/Edu_Psy/EP_03_New.pdf

Wray, D. \& Medwell, J. (2006). Progression in writing and the Northern Ireland levels for writing. A research review undertaken for CCEA. http://www2.warwick.ac.uk/fac/soc/ces/research/teachingandlearning/resactivities/subject s/literacy/ccea/

Yates, C., Berninger, V. \& Abbott, R. (1995). Specific writing disabilities in intellectually gifted children. Journal for the Education of the Gifted, 18(2), 131-155. http://jeg.sagepub.com/content/18/2/131.full.pdf

Appendix A

Writing Protocol and Prompt: 'The Empty Space'

Name:

Homeroom:

Grade:

Do you speak another language at home? If yes, which language?

Where were you born? If not in Canada, how old were you when you immigrated?

WRITING TASK

Imagine that there is a large undeveloped space in your schoolyard. Every student in the school has been asked for ideas about what to put there. A committee of teachers and parents will choose the best suggestion.

Describe what you would put in the space. Then, convince the committee that your idea is the best way to use the space.

DIRECTIONS FOR WRITING

Students have up to 60 minutes to plan and write, so budget the time carefully.

Use the PLANNING page to plan the writing. Students are encouraged to draw, color, brainstorm, web or list ideas, and think of details that will be interesting and entertaining.

Use the WRITING pages to write a first draft. Students may show changes and corrections on the first draft. Do not write a 'good copy'. If students need more space to write, use the back of the writing pages. Please number the extra pages.

The work will be evaluated on WHAT students write and HOW WELL they write. Remember to:

- CONSIDER your audience 
- $\quad$ PRESENT your ideas in prose

- $\quad$ ORGANIZE your writing as required by the task

- $\quad$ FOCUS on the purpose of your writing

Appendix $B$

Scoring rubric - Performance Criteria Grid Format

\begin{tabular}{|c|c|c|c|c|}
\hline $\begin{array}{c}\text { WRITING } \\
\text { ELEMENTS }\end{array}$ & $\begin{array}{c}4 \\
\text { EXCELLENT }\end{array}$ & $\begin{array}{c}3 \\
\text { PROFICIENT }\end{array}$ & $\begin{array}{c}2 \\
\text { ADEQUATE }\end{array}$ & $\begin{array}{c}1 \\
\text { LIMITED }\end{array}$ \\
\hline $\begin{array}{c}\text { TASK } \\
\text { FULFILLMENT }\end{array}$ & $\begin{array}{l}\text { The writer } \\
\text { fulfills the task } \\
\text { and } \\
\text { purposefully } \\
\text { crafts a } \\
\text { convincing } \\
\text { proposal. }\end{array}$ & $\begin{array}{l}\text { The writer } \\
\text { fulfills the task } \\
\text { and uses } \\
\text { supportive } \\
\text { details to } \\
\text { present a } \\
\text { credible } \\
\text { proposal. }\end{array}$ & $\begin{array}{l}\text { The writer } \\
\text { addresses the } \\
\text { task, and uses } \\
\text { sufficient } \\
\text { details to make } \\
\text { a plausible } \\
\text { proposal. }\end{array}$ & $\begin{array}{l}\text { The writer } \\
\text { addresses the } \\
\text { task to some } \\
\text { degree and } \\
\text { shares a sketchy } \\
\text { proposal. }\end{array}$ \\
\hline $\begin{array}{c}\text { UNITY AND } \\
\text { COHERENCE }\end{array}$ & $\begin{array}{l}\text { The paper } \\
\text { shows overall } \\
\text { unity and } \\
\text { reasoning is } \\
\text { compelling. }\end{array}$ & $\begin{array}{l}\text { The paper reads } \\
\text { smoothly and } \\
\text { reasoning is } \\
\text { systematic and } \\
\text { believable. }\end{array}$ & $\begin{array}{l}\text { The paper } \\
\text { generally reads } \\
\text { smoothly and } \\
\text { reasoning has a } \\
\text { resemblance of } \\
\text { actuality. }\end{array}$ & $\begin{array}{l}\text { The paper is } \\
\text { often awkward } \\
\text { to read and } \\
\text { reasoning } \\
\text { displays } \\
\text { inconclusive } \\
\text { support. }\end{array}$ \\
\hline AUDIENCE & $\begin{array}{l}\text { The writing } \\
\text { sustains the } \\
\text { reader's interest } \\
\text { and engages the } \\
\text { audience. }\end{array}$ & $\begin{array}{l}\text { A consideration } \\
\text { of audience is } \\
\text { maintained } \\
\text { throughout the } \\
\text { writing. }\end{array}$ & $\begin{array}{l}\text { A consideration } \\
\text { of audience is } \\
\text { conveyed but } \\
\text { may not be } \\
\text { sustained } \\
\text { throughout. }\end{array}$ & $\begin{array}{l}\text { Consideration of } \\
\text { audience may be } \\
\text { vague. }\end{array}$ \\
\hline $\begin{array}{c}\text { CONTENT AND } \\
\text { TOPIC } \\
\text { DEVELOPMENT }\end{array}$ & $\begin{array}{l}\text { The ideas are } \\
\text { focused and } \\
\text { purposeful; } \\
\text { topic } \\
\text { development is } \\
\text { skillful. }\end{array}$ & $\begin{array}{l}\text { The ideas are } \\
\text { clear and } \\
\text { interesting; } \\
\text { topic } \\
\text { development is } \\
\text { effective. }\end{array}$ & $\begin{array}{l}\text { The ideas are } \\
\text { general and } \\
\text { often repetitive; } \\
\text { topic } \\
\text { development is } \\
\text { predictable. }\end{array}$ & $\begin{array}{l}\text { The ideas are } \\
\text { reasonable but } \\
\text { often } \\
\text { underdeveloped; } \\
\text { topic } \\
\text { development is } \\
\text { superficial. }\end{array}$ \\
\hline $\begin{array}{c}\text { VOCABULARY } \\
\text { AND USAGE }\end{array}$ & $\begin{array}{l}\text { Vocabulary and } \\
\text { usage are often } \\
\text { clever, and } \\
\text { chosen } \\
\text { intentionally for } \\
\text { the form and } \\
\text { purpose. }\end{array}$ & $\begin{array}{l}\text { Vocabulary and } \\
\text { usage choices } \\
\text { are precise and } \\
\text { suitable for the } \\
\text { form and } \\
\text { purpose. }\end{array}$ & $\begin{array}{l}\text { Vocabulary and } \\
\text { usage choices } \\
\text { are generally } \\
\text { suitable for the } \\
\text { form and } \\
\text { purpose. }\end{array}$ & $\begin{array}{l}\text { Vocabulary and } \\
\text { usage choices } \\
\text { are within a } \\
\text { narrow range. }\end{array}$ \\
\hline $\begin{array}{c}\text { ORGANIZATION } \\
\text { AND STYLE }\end{array}$ & $\begin{array}{l}\text { The } \\
\text { organization of }\end{array}$ & $\begin{array}{l}\text { The } \\
\text { organization of }\end{array}$ & $\begin{array}{l}\text { The } \\
\text { organization of }\end{array}$ & $\begin{array}{l}\text { There is } \\
\text { evidence of }\end{array}$ \\
\hline
\end{tabular}




\begin{tabular}{|c|c|c|c|c|}
\hline & $\begin{array}{l}\text { the paper is } \\
\text { controlled, and } \\
\text { the style creates } \\
\text { a sense of voice } \\
\text { unique to the } \\
\text { writer. }\end{array}$ & $\begin{array}{l}\text { the paper is } \\
\text { logical and the } \\
\text { voice and style } \\
\text { are appropriate. }\end{array}$ & $\begin{array}{l}\text { the paper is } \\
\text { straightforward } \\
\text { and may } \\
\text { ramble. }\end{array}$ & $\begin{array}{l}\text { difficulty in } \\
\text { organizing } \\
\text { ideas. }\end{array}$ \\
\hline MECHANICS & $\begin{array}{l}\text { Spelling, } \\
\text { grammar, } \\
\text { capitalization } \\
\text { and punctuation } \\
\text { applications are } \\
\text { controlled to } \\
\text { enhance the } \\
\text { impact of } \\
\text { writing; errors } \\
\text { are hardly } \\
\text { noticeable. }\end{array}$ & $\begin{array}{l}\text { Spelling, } \\
\text { grammar, } \\
\text { capitalization } \\
\text { and punctuation } \\
\text { applications are } \\
\text { effective; errors } \\
\text { are few and do } \\
\text { not interfere } \\
\text { with the } \\
\text { writer's } \\
\text { intended } \\
\text { meaning. }\end{array}$ & $\begin{array}{l}\text { Spelling, } \\
\text { grammar, } \\
\text { capitalization } \\
\text { and punctuation } \\
\text { applications are } \\
\text { uncomplicated; } \\
\text { errors are } \\
\text { evident and do } \\
\text { not } \\
\text { significantly } \\
\text { interfere with } \\
\text { the writer's } \\
\text { intended } \\
\text { meaning. }\end{array}$ & $\begin{array}{l}\text { Spelling, } \\
\text { grammar, } \\
\text { capitalization } \\
\text { and punctuation } \\
\text { applications are } \\
\text { inconsistent; } \\
\text { errors may } \\
\text { interfere with } \\
\text { the writer's } \\
\text { intended } \\
\text { meaning. }\end{array}$ \\
\hline
\end{tabular}

\section{Author Biographies}

Hetty Roessingh is a longtime ESL practitioner in the Calgary Board of Education, and is currently a professor in the Werklund School of Education, University of Calgary where she teaches in both the undergraduate and graduate programs. Research interests include longitudinal studies investigating the development of academic literacy over time for all students in the $\mathrm{k}-12$ educational trajectory.

Scott Douglas is on Faculty at UBC, where he teaches in the undergraduate and graduate programs. His research interests focus on the features of lexical diversity and sophistication that are the hallmarks of quality writing over time, and developing strategies for interventions to close the gap. He is the author of several books on classroom practice for adult ESL learners.

Brock Wojtalewicz is a recent MA graduate from the Werklund School of Education, University of Calgary. His research interest is in children's development of academic literacy. 